\title{
Design and Improve Coatings for some Antennas
}

\author{
Ghasak T. Suhail and Saeed N. Turki \\ Physics Department, Education College for Pure Sciences, Anbar University, Anbar, Iraq
}

\begin{abstract}
In this paper, antireflection coating is designed for helical and loop antennas depending on the variable of refractive indices for microwave region of electromagnetic spectrum by use characteristic matrix method in computer program MATLAB version 7. helical antenna works within the range $\left(\{3.12-6.66\} \times 10^{8} \mathrm{~nm}\right)$ it has copper as a substrate. The results shows that, for the normal incidence, the reflectance of copper reduced from $(17.38 \%)$ to $(0.1065 \%)$ when coated by two layer $\mathrm{MgO}$ and $\mathrm{BeO}$ as low and high index coating materials respectively according to the design $[\mathrm{Air} / \mathrm{LH} / \mathrm{Cu}]$. Also the effect of angle of incidence on the reflectance spectrum of this design are investigate. And loop antenna works within the range $\left(\{3.48-9.67\} \times 10^{8} \mathrm{~nm}\right)$ it has zinc as a substrate. The results shows that, for the normal incidence, the reflectance of zinc reduced from $(11.11 \%)$ to $(0.06242 \%)$ when coated by the layer $\mathrm{SiO}_{2}$ according to the design [Air/L/Zn]. The results shows that the reflectance are increases with shifting toward shorter wavelengths.
\end{abstract}

Keywords: - design, coating, microwave, antenna

\section{INTRODUCTION}

Microwaves are a form of electromagnetic radiation with frequencies ranging from several hundred $\mathrm{MHz}$ to several hundred $\mathrm{GHz}$ and wavelengths ranging from approximately 1 to 20 centimeters. Because of their high frequencies, microwaves have the advantage of being able to carry more information than ordinary radio waves and are capable of being beamed directly from one point to another[1].The majority of today's applications of microwave technology are to wireless networking and communications systems, wireless security systems, radar systems, environmental remote sensing, and medical systems[2]. antennas are considered the device used in wireless communications, A metal device used for the transmission and receiving of electromagnetic waves, and this device one of the most commonly used devices and widespread because his applications in military and peaceful purposes. Antennas made of metals that have a high conductivity, such as aluminum, copper, iron, gold, etc., and gold is used in small antennas, such as those used in mobile and satellite working in the frequency range of the microwave (Microwave Band)When the transmitter is antennas converts electrical waves coming forth to electromagnetic waves spread from there to the outer perimeter and when the receiver is receiving antennas to receive electromagnetic waves and convert them after a number of operations to electric waves [3] , and lead antennas its highest efficiency and less loss of signal, and classified antennas based on factors, including the frequency and polarization and radiation and design, There are several types are used for different purposes, including antenna parabola (Parabolic antenna), grid (Grid antenna), spiral (Helical antenna), loop (Loop antenna), yagi (Yagi antenna) and horn (Horn antenna) and other types [4] .

When the electromagnetic wave is incident on plane surface bonding two substances of indices $n$ and $\mathrm{n}^{-}$, this wave suffer absorption $\mathrm{A}$, reflection $\mathrm{R}$, dispersion $\mathrm{S}$ and transmittance $\mathrm{T}$, according to Equation (1)[5]:

$\mathrm{T}+\mathrm{R}+\mathrm{A}+\mathrm{S}=1$

This is the law of conservation of energy, when the materials are homogeneous and flat surfaces, the dispersion can not happen and when use thin films, the absorbance neglected because small thickness of films and the equation(1) becomes[6]:

$$
\mathrm{R}+\mathrm{T}=1
$$

The phenomena of reflection and transmission are important for many scientific applications ,the amount of radiation reflected or transmitted based on a set of optical properties such as the refractive index of the two mediums and the wavelength of the incident beam and the angle of incidence in addition to the quality of the surface material (metal or dielectric)[7,8]. Designed to reduce the transmitted waves reflective coatings, multilayer optical thin film coating has extensively been used for reflectivity modulation in various optical and optoelectronic components [9] , It's has a wide range of applications, such as displays; camera lenses, mirrors, and filters; eyeglasses; mirrors, laser windows, and polarizes; optics of photocopiers and compact disks; optical communications; home appliances, such as heat reflecting oven windows $[9,10]$, to reduce the large losses in the amount of transmitted radiation designed anti-reflective coatings and with use thin-film technology to reduce the energy lost, The areas of application for ARCs can be divided in two main categories: applications in which the ARC is used for aesthetic purposes and applications in which the ARC is used to improve the efficiency of devices. Examples of the first category are eye glasse, museum and picture glass and displays [11-14]. Examples of the second category are lenses and devices that convert electromagnetic waves to electricity and 
vice versa, like antennas [11,12,15-20]. Much attention has been paid in recent literature to the use of ARCs in such solar and lighting devices [21].increase or decrease the reflectivity depends on the principle of constructive and destructive interference respectively, interference construction occurs when the rays reflected from the surfaces of thin films in the same phase, constructive interference occurs when the rays reflected in the different phases[1].

\section{THEORETICAL BASIS}

The Fresnel amplitude reflection coefficient ( $r$ ) for an interface between two Non-absorbing media at normal incidence can be represented by the following equation [22]:

$$
r=\frac{n \circ-n_{1}}{n \circ+n_{1}}
$$

where $\mathrm{n}_{\mathrm{o}}$ is the refractive index of the incident medium and $\mathrm{n}_{\mathrm{s}}$ is the refractive index of the substrate. The reflectance $\mathrm{R}$, given by[23]:

$$
R=r r^{*}
$$

from equation (3), equation (4) becomes:

$$
R=\left(\frac{n_{\circ}-n_{1}}{n \circ+n_{1}}\right)^{2}
$$

Became possible expression about system consists of several layers by Characteristic matrices, a square matrix (2x2), which describes the characteristics of the each flim and the angle of incidence and polarization pattern, of the form:

$\left[M_{j}\right]=\left(\begin{array}{cc}\cos \delta_{j} & i \sin \delta_{j} / \eta_{L} \\ i n_{L} \sin \delta_{j} & \cos \delta_{j}\end{array}\right)$

where $\eta \mathrm{j}$ is the effective refractive index of the layer, $\delta \mathrm{j}$ is its phase thickness, for assembly of layers $(\mathrm{Z})$, the characteristic matrix become[24]:

$$
\left(\begin{array}{l}
B \\
C
\end{array}\right)=\prod_{r=1}^{Z}\left(\begin{array}{cc}
\cos \delta_{r} & i \sin \delta_{r} / \eta_{r} \\
i n_{L} \sin \delta_{r} & \cos \delta_{r}
\end{array}\right)\left(\begin{array}{c}
1 \\
\eta_{\text {Sub }}
\end{array}\right)
$$

where $\eta_{r}=n / \cos \theta$ for P-polarization , $\eta_{r}=n \cos \theta$ for S-polarization, $\mathrm{B}$ and $\mathrm{C}$ are the total electric and magnetic field amplitudes.

$$
\delta_{r}=\frac{2 \pi n_{r} d_{r} \cos \theta_{r}}{\lambda}
$$

$\mathrm{n}_{\mathrm{r}} \mathrm{d}_{\mathrm{r}}$ : optical thickness for layer. The multilayer can be replaced by a single surface, which has an input optical admittance $\mathrm{Y}$ given by $(\mathrm{Y}=\mathrm{B} / \mathrm{C}), \mathrm{Y}$ is the admittance presented to the incident wave by the coating. equation(8) include all information for assembly of multilayer, reflectivity and transmittance can obtained for oblique incident of wave from two following equation[25]:

$$
\begin{gathered}
R=\left(\frac{\eta_{o} B-C}{\eta_{o} B+C}\right)\left(\frac{\eta_{o} B-C}{\eta_{o} B+C}\right)^{*} \\
T=\frac{4 \eta_{o} \operatorname{Re}\left(\eta_{s u b}\right)}{\left(\eta_{o} B+C\right)\left(\eta_{o} B+C\right)^{*}}
\end{gathered}
$$

\section{RESULTS AND DISCUSSION}

We design a computer program using MATLAB version 7 to calculate and reduce the reflectivity for helical and loop antenna which works as receiving antenna within microwave. This program depends on refractive index of materials (coating), number of layers and incident angle.

At first for helical antenna, it works within the range $\left(\{3.12-6.66\} \times 10^{8} \mathrm{~nm}\right)$. we use copper as a substrate .For the normal incidence, the reflectance of $\mathrm{Cu}$ as a function of wavelength are shown in figure (1). It show that the reflectance ( $\mathrm{R} \sim 17.38 \%)$. $\mathrm{MgO}$ and $\mathrm{BeO}$ using as low and high index coating materials, the design [Air / $\mathrm{LH}$ $/ \mathrm{Cu}$ ] have minimum reflectance (high transmittance) at design wavelength as show in figure(2). So, we using this design to study the effect of angle of incident and on the performance of this design. Figure (3-6) shows the effect of angle of incident on the reflectance as a function of wavelength. 


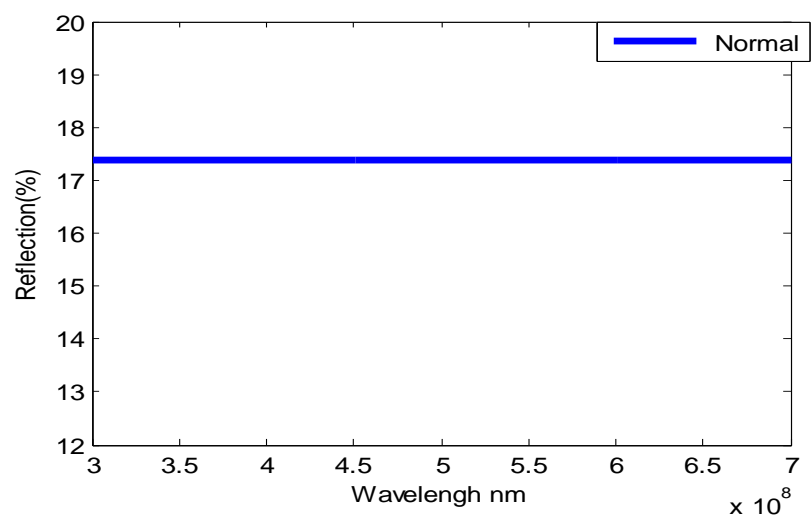

Figure 1: Reflectance as a function of wavelength of Copper from air.

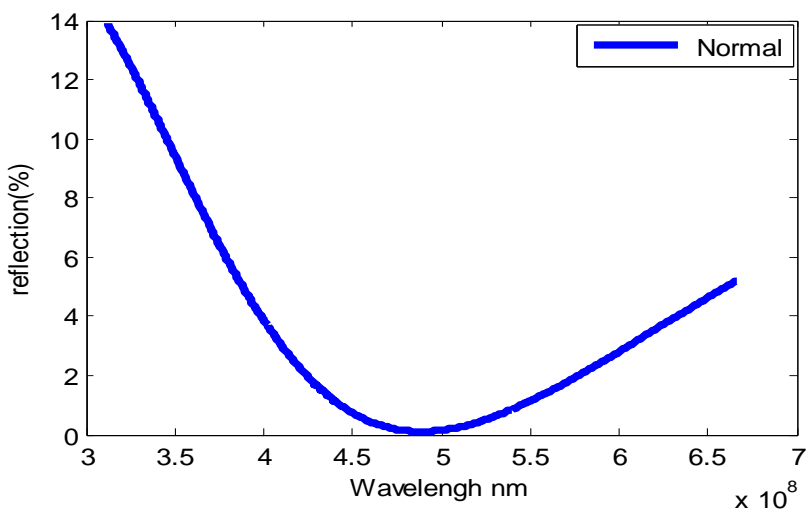

Figure 2: Reflectance as a function of wavelength of the design Air / $\mathrm{LH} / \mathrm{Cu}, \mathrm{n}_{\mathrm{L}}=1.71, \mathrm{n}_{\mathrm{H}}=2.58, \mathrm{n}_{\mathrm{sub}}=2.43$, $\lambda_{0}=5 \times 10^{8} \mathrm{~nm}$, normal incidence $\left(\theta_{0}=0 \%\right.$.

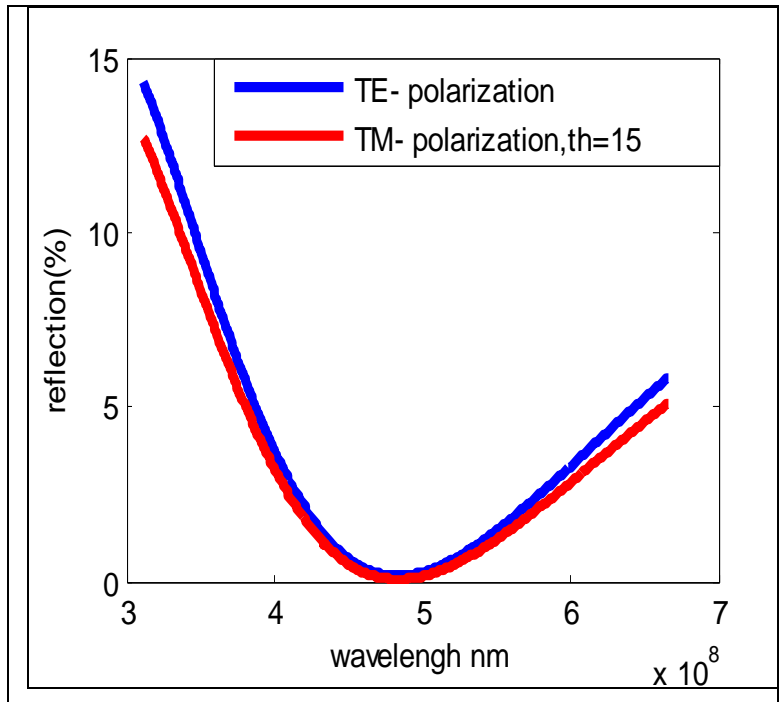

Figure 3: Reflectance as a function ofwavelength of the design Air / $\mathrm{LH} / \mathrm{Cu}, \mathrm{n}_{\mathrm{L}}=1.71, \mathrm{n}_{\mathrm{H}}=2.58$, $\mathrm{n}_{\mathrm{sub}}=2.43, \lambda_{\mathrm{o}}=5 \times 10^{8} \mathrm{~nm}$, oblique incidence $\left(\theta_{\mathrm{o}}=15^{\circ}\right)$.

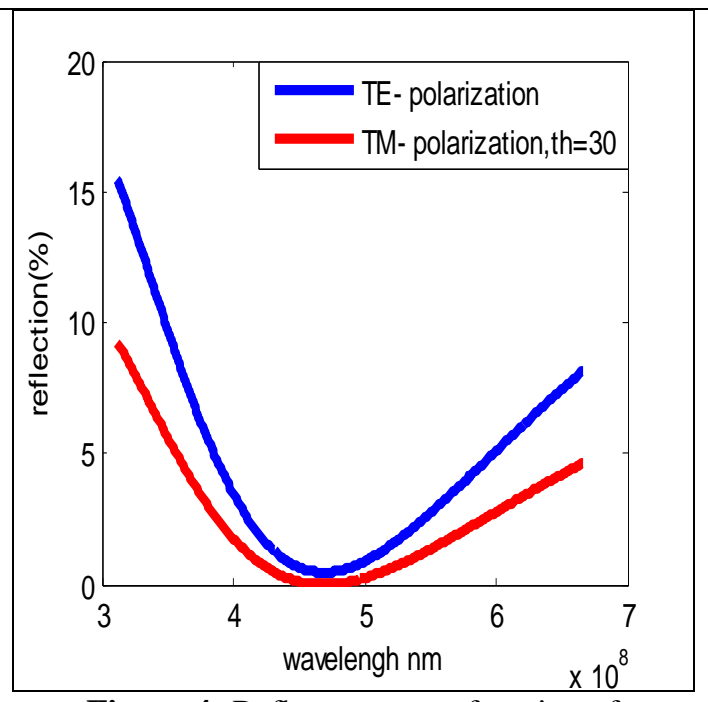

Figure 4: Reflectance as a function of wavelength of the design Air / $\mathrm{LH} / \mathrm{Cu}, \mathrm{n}_{\mathrm{L}}$ $=1.71, \mathrm{n}_{\mathrm{H}}=2.58, \mathrm{n}_{\text {sub }}=2.43, \lambda_{\mathrm{o}}=5 \times 10^{8} \mathrm{~nm}$, oblique incidence $\left(\theta_{0}=30^{\circ}\right)$. 


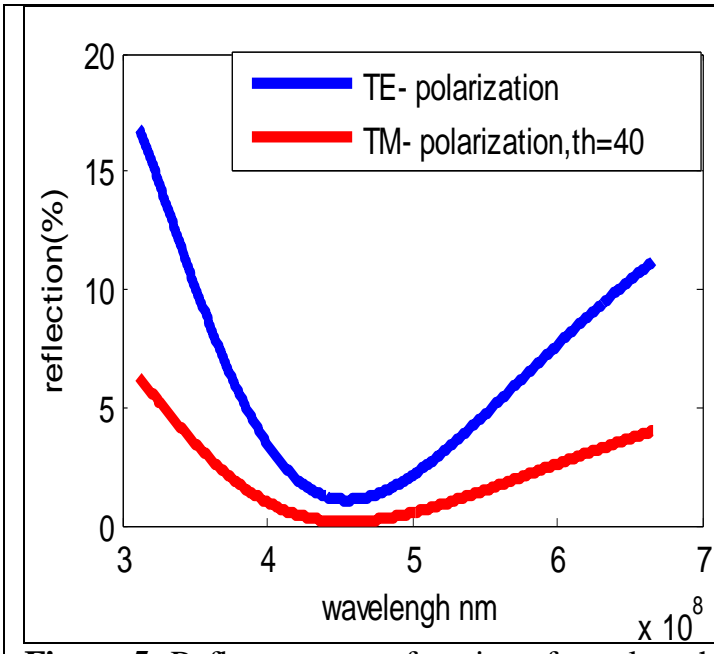

Figure 5: Reflectance as a function ofwavelength of the design Air / $\mathrm{LH} / \mathrm{Cu}, \mathrm{n}_{\mathrm{L}}=1.71, \mathrm{n}_{\mathrm{H}}=2.58$, $\mathrm{n}_{\text {sub }}=2.43, \lambda_{\mathrm{o}}=5 \times 10^{8} \mathrm{~nm}$, oblique incidence $\left(\theta_{\mathrm{o}}=40^{\circ}\right)$.

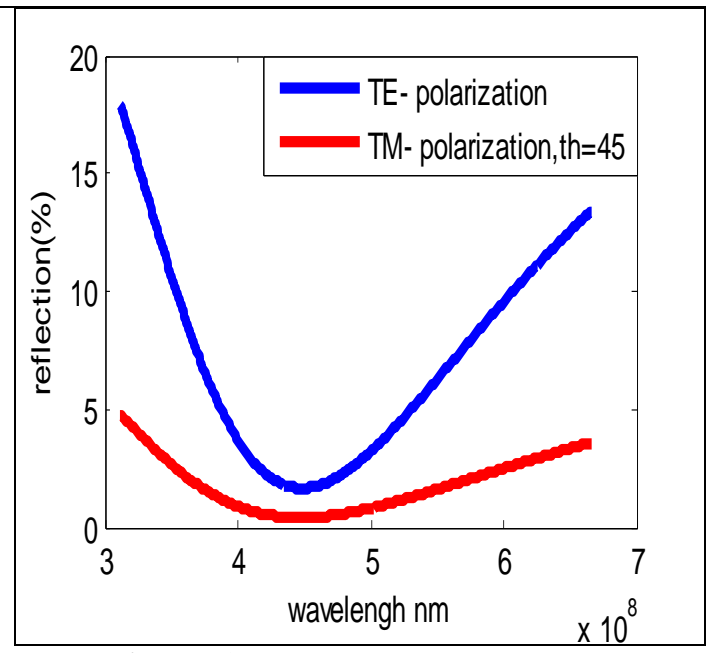

Figure 6: Reflectance as a function ofwavelength of the design Air / $\mathrm{LH} / \mathrm{Cu}, \mathrm{n}_{\mathrm{L}}$ $=1.71, \mathrm{n}_{\mathrm{H}}=2.58, \mathrm{n}_{\mathrm{sub}}=2.43, \lambda_{\mathrm{o}}=5 \times 10^{8} \mathrm{~nm}$, oblique incidence $\left(\theta_{\mathrm{o}}=45^{\circ}\right)$.

Table 1: Varying effect angle of incidence on the design Air / LH / Cu for helical antenna

\begin{tabular}{|c|c|c|c|c|c|}
\hline $\begin{array}{c}\text { Number of } \\
\text { figure }\end{array}$ & $\begin{array}{c}\text { Coating } \\
\text { materials }\end{array}$ & Substrate & $\begin{array}{c}\text { Angle of } \\
\text { incidence }\end{array}$ & $\begin{array}{l}\text { Wavelength } \\
\mathrm{nm}\left(\mathrm{x}^{\mathrm{s}}{ }^{\mathrm{s}}\right)\end{array}$ & $\begin{array}{c}\text { Reflectance } \\
\mathbf{R} \%\end{array}$ \\
\hline 2 & $\begin{array}{l}\mathrm{BeO} \\
\mathrm{MgO}\end{array}$ & Copper & $0^{\circ}$ & $(4.578)$ & $=0.1065$ \\
\hline 3 & $\begin{array}{l}\mathrm{BeO} \\
\mathrm{MgO}\end{array}$ & Copper & $15^{\circ}$ & $\begin{array}{l}(4.84) \\
(4.84)\end{array}$ & $\begin{array}{c}S=0.1647 \\
\mathrm{P}=0.06103\end{array}$ \\
\hline 4 & $\begin{array}{l}\mathrm{BeO} \\
\mathrm{MgO}\end{array}$ & Copper & $30^{\circ}$ & $\begin{array}{l}(4.692) \\
(4.692)\end{array}$ & $\begin{array}{c}\mathrm{S}=0.4648 \\
\mathrm{P}=0.0008225\end{array}$ \\
\hline 5 & $\begin{array}{l}\mathrm{BeO} \\
\mathrm{MgO}\end{array}$ & Copper & $40^{\circ}$ & $\begin{array}{c}(4.55-4.564) \\
(4.55)\end{array}$ & $\begin{array}{c}S=1.071 \\
P=0.1454\end{array}$ \\
\hline 6 & $\begin{array}{l}\mathrm{BeO} \\
\mathrm{MgO}\end{array}$ & Copper & $45^{\circ}$ & $\begin{array}{l}(4.479) \\
(4.472)\end{array}$ & $\begin{array}{c}S=1.657 \\
\mathrm{P}=0.4022\end{array}$ \\
\hline
\end{tabular}

for loop antenna, it works within the range $\left(\{3.48-9.67\} \times 10^{8} \mathrm{~nm}\right)$. we use zinc as a substrate. For the normal incidence, the reflectance of $\mathrm{Zn}$ as a function of wavelength are shown in figure (7). It show that the reflectance ( $\mathrm{R} 11.11 \%) . \mathrm{SiO}_{2}$ using as low coating materias, the design [Air / L /Zn] have minimum reflectance (high transmittance) at design wavelength as show in figure(8). So, we using this design to study the effect of angle of incident and on the performance of this design. Figure (9-12) shows the effect of angle of incident on the reflectance as a function of wavelength. When angle of incidence increase the reflectance increase with shift toward shorter wavelengths, this shift may be as result of varying the optical thickness of layer due to the oblique incidence of plane electromagnetic wave.

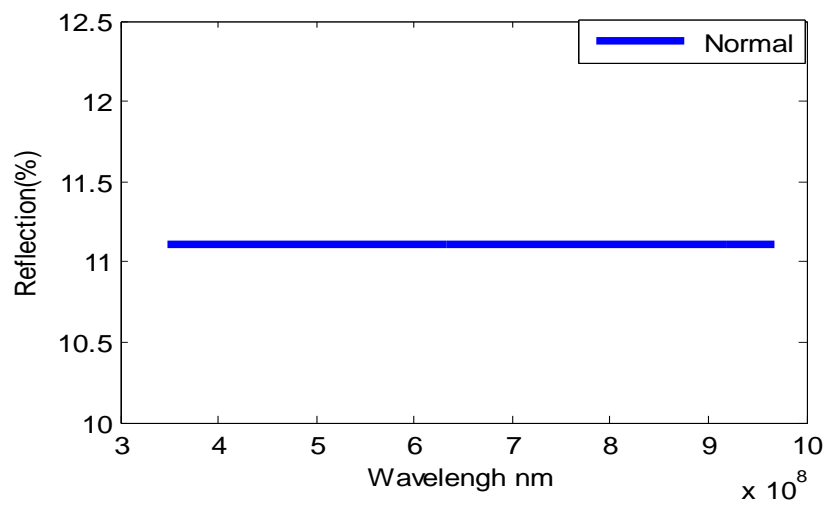

Figure 7: Reflectance as a function of wavelength of Zinc from air 


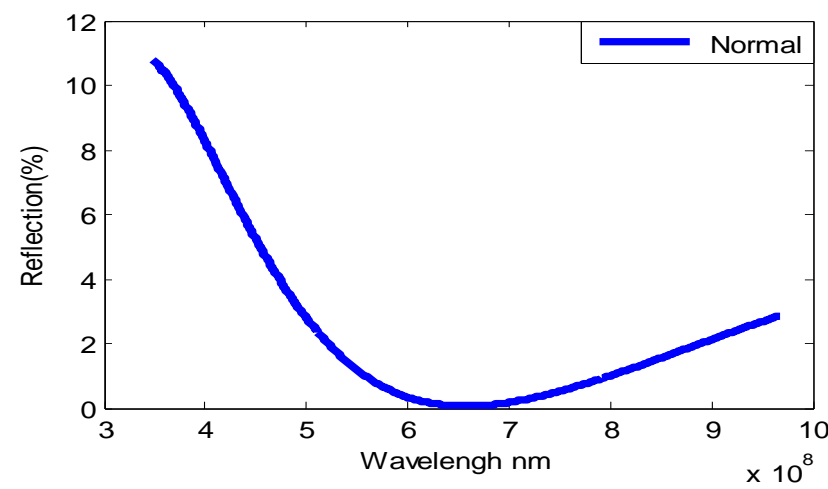

Figure 8: Reflectance as a function of wavelength of the design Air / $\mathrm{L} / \mathrm{Zn}, \mathrm{n}_{\mathrm{L}}=1.45, \mathrm{n}_{\text {sub }}=2, \lambda_{0}=6.575 \times 10^{8}$ $\mathrm{nm}$, normal incidence $\left(\theta_{0}=0\right.$ ).

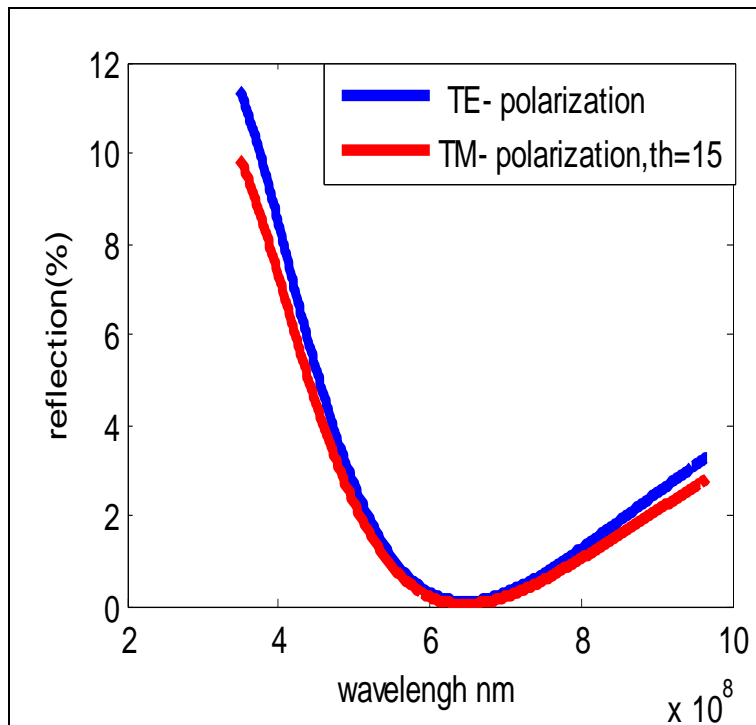

Figure 9: Reflectance as a function of wavelength of the design Air $/ \mathrm{L} / \mathrm{Zn}, \mathrm{n}_{\mathrm{L}}=1.45, \mathrm{n}_{\text {sub }}=2$, $\lambda_{0}=6.575 \times 10^{8} \mathrm{~nm}$, oblique incidence $\left(\theta_{0}=15^{\circ}\right)$.

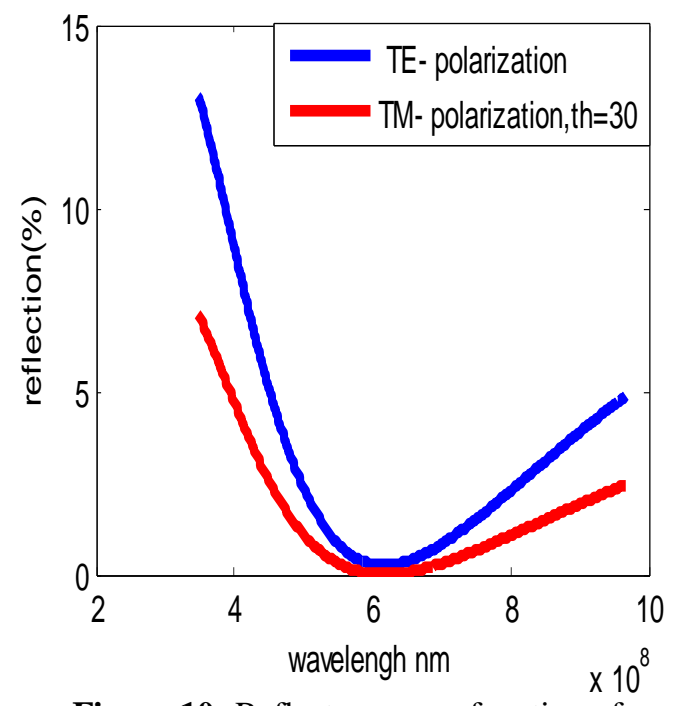

Figure 10: Reflectance as a function of wavelength of the design Air / $\mathrm{L} / \mathrm{Zn}, \mathrm{n}_{\mathrm{L}}=1.45$, $\mathrm{n}_{\text {sub }}=2, \lambda_{\mathrm{o}}=6.575 \times 10^{8} \mathrm{~nm}$, oblique incidence $\left(\theta_{0}=30^{\circ}\right)$. 


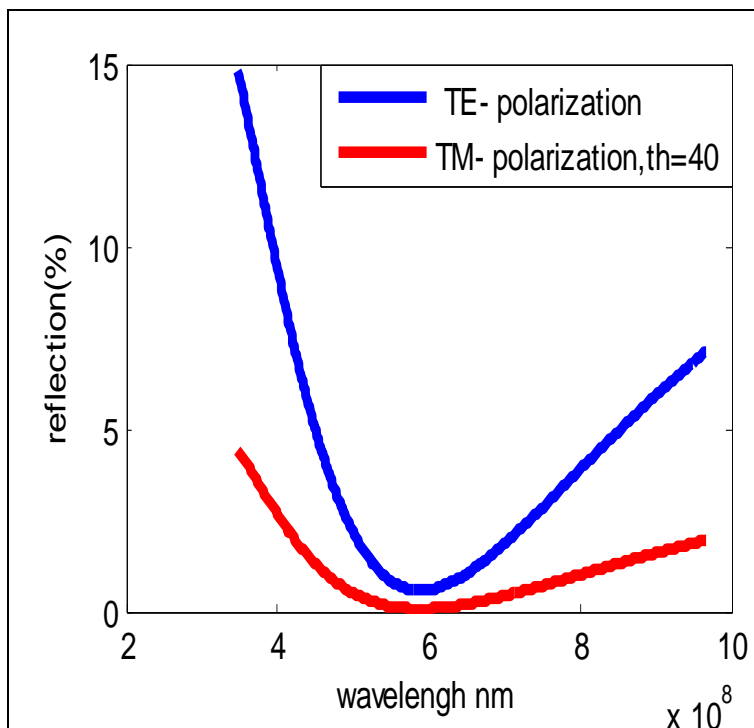

Figure 11: Reflectance as a function of wavelength of the design Air / $\mathrm{L} / \mathrm{Zn}, \mathrm{n}_{\mathrm{L}}=1.45, \mathrm{n}_{\text {sub }}=2$, $\lambda_{\mathrm{o}}=6.575 \times 10^{8} \mathrm{~nm}$, oblique incidence $\left(\theta_{0}=40^{\circ}\right)$.

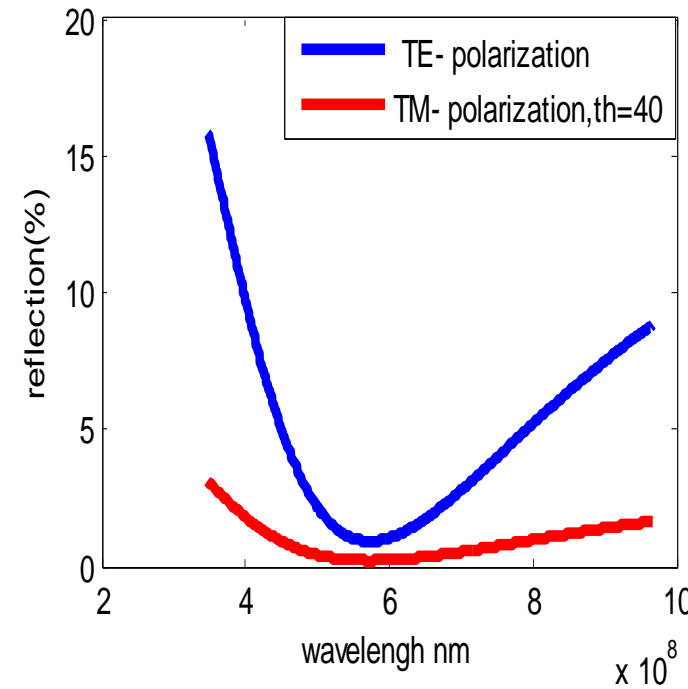

Figure 12: Reflectance as a function of wavelength of the design Air / L / Zn, $\mathrm{n}_{\mathrm{L}}=1.45$, $\mathrm{n}_{\mathrm{sub}}=2, \lambda_{\mathrm{o}}=6.575 \times 10^{8} \mathrm{~nm}$, oblique incidence $\left(\theta_{0}=45^{\circ}\right)$.

Table 2: Varying effect angle of incidence on the design Air / L /Zn for loop antenna

\begin{tabular}{|c|c|c|c|c|c|}
\hline $\begin{array}{c}\text { Number of } \\
\text { figure }\end{array}$ & $\begin{array}{c}\text { Coating } \\
\text { material }\end{array}$ & Substrate & $\begin{array}{c}\text { Angle of } \\
\text { incidence }\end{array}$ & $\begin{array}{c}\text { Wavelength } \\
\text { nm (x10 }\end{array}$ & $\begin{array}{c}\text { Reflectance } \\
\mathbf{R} \%\end{array}$ \\
\hline 8 & $\mathrm{SiO}_{2}$ & $\mathrm{Zinc}$ & $0^{\circ}$ & $(6.575)$ & $=0.06242$ \\
\hline 9 & $\mathrm{SiO}_{2}$ & $\mathrm{Zinc}$ & $15^{\mathbf{0}}$ & $\begin{array}{r}(6.464) \\
(6.464)\end{array}$ & $\begin{array}{r}\mathrm{S}=0.09212 \\
\mathrm{P}=0.03852\end{array}$ \\
\hline 10 & $\mathrm{SiO}_{2}$ & $\mathrm{Zinc}$ & $30^{\circ}$ & $\begin{array}{c}(6.166) \\
(6.191)\end{array}$ & $\begin{array}{c}\mathrm{S}=0.2471 \\
\mathrm{P}=0.000218\end{array}$ \\
\hline 11 & $\mathrm{SiO}_{2}$ & $\mathrm{Zinc}$ & $40^{\circ}$ & $\begin{array}{c}(5.894) \\
(5.894)\end{array}$ & $\begin{array}{c}\mathrm{S}=0.577 \\
\mathrm{P}=0.06822\end{array}$ \\
\hline 12 & $\mathrm{SiO}_{2}$ & $\mathrm{Zinc}$ & $45^{\circ}$ & $(5.77)$ & $\mathrm{S}=0.09212$ \\
& & & & $(5.733-5.746)$ & $\mathrm{P}=0.03852$ \\
\hline
\end{tabular}

IV.

\section{CONCLUSION}

The results obtained from this work are essential in the design of antireflection coating for helical and loop antennas to minimize the reflectance of received radiation. coating of helical antenna $\mathrm{MgO}$ and $\mathrm{BeO}$ as low and high index coating materials respectively according to the design [Air/LH/Cu] gives the best ruslt $\mathrm{R}=0.1065 \%$ at $\theta=0^{\circ}, \mathrm{R}=0.46480 .2471 \%$ for $\mathrm{S}$-Pol and $\mathrm{R}=0.0008225 \%$ for P-Pol at $\theta=30^{\circ}$. coating of loop antenna $\mathrm{SiO}_{2}$ low index coating material according to the design [Air/L/Zn] gives the best ruslt $\mathrm{R}=0.06242 \%$ at $\theta=0^{\circ}, \mathrm{R}=0.2471 \%$ for $\mathrm{S}-\mathrm{Pol}$ and $\mathrm{R}=0.000218 \%$ for $\mathrm{P}-\mathrm{Pol}$ at $\theta=30^{\circ}$. when the incident angle of radiation increase the reflectance increase for both TE- mode ( $\mathrm{S}$ - Polarization) and TM- mode (P- Polarization) due to oblique incidence which leads to varying in optical thickness of layers of suggested design with shifting to the reflectance spectrum toward shorter wavelength region.

\section{REFERENCES}

[1] J.C. Maxwell, “A Treatise on Electricity and Magnetism”, Vol.1-2, Oxford, 1873.

[2] David M. Pozar "Microwave Engineering", John Wiley \& Sons, 2012, 2005, 1998.

[3] C.A. Balanis, „Antenna theory: analysis and design ${ }^{\text {eeee }}$, 2nd ed., John Willey and \& Son, Inc., 1997.

[4] C. Ingale, T. Ingale, A. Trikolikar, "Study of different Types of Microwave Antenna and Its Application" International Journal of computer Technology and Electronics Engineering, Vol 3, special Issue, MarchApril 2013, PP. 103-106.

[5] Stenzel, O. (2005). The Physics of Thin Film Optical Spectra. Berlin, Heidelberg: Springer. http://dx.doi.org/10.1007/3-540-27905-9

[6] wai-Sze T. Lam, "optical interference coating s" The University of Arizona,2005. 
[7] F.A. Genkins and H.E. White, Fundamental of Optics (McGraw-Hill-Kogakusha, Ltd, 1981).

[8] K.L. Chopra, Thin Film Phenomena (McGraw-Hill Company, New York, 1989).

[9] Kheraj, V. A., Panchal, C. J., Desai, M. S., \& Potbhare, V. ( 2008). Simulation of reflectivity spectrum for non-absorbing multilayer optical thin films. Springer-Verlag. http://dx.doi.org/10.1007/s12043-0090081-0.

[10] Sophocles, J. O. (1999-2010). Electromagnetic Waves and Antennas. Rutgers University

[11] MacLeod, H.A.; MacLeod, A. Thin-Film Optical Filters; CRC Press: Bristol, UK, 2001.

[12] Chen, D. Anti-reflection (AR) coatings made by sol-gel processes: A review. Sol. Energy Mater. Sol. Cells 2001, 68, 313-336. Materials 2013, 63723

[13] Ibn-Elhaj, M.; Schadt, M. Optical polymer thin films with isotropic and anisotropic nano-corrugated surface topologies. Nature 2001, 410, 796-799.

[14] Chen, D.; Yan, Y.; Westenberg, E.; Niebauer, D.; Sakaitani, N.; Chaudhuri, S.R.; Sato, Y.; Takamatsu, M. Development of anti-reflection (AR) coating on plastic panels for display applications. J. Sol-Gel Sci. Technol. 2000, 19, 77-82.

[15] Schottner, G.; Rose, K.; Posset, U. Scratch and abrasion resistant coatings on plastic lenses-State of the art, current developments and perspectives. J. Sol-Gel Sci. Technol. 2003, 27, 71-79.

[16] Gombert, A.; Glaubitt, W.; Rose, K.; Dreibholz, J.; Bläsi, B.; Heinzel, A.; Sporn, D.; Döll, W.; Wittwer, V. Anti-reflective transparent covers for solar devices. Sol. Energy 2000, 68, 357-360.

[17] Gombert, A.; Glaubitt, W.; Rose, K.; Dreibholz, J.; Bläsi, B.; Heinzel, A.; Sporn, D.; Döll, W.; Wittwer, V. Subwavelength-structured antireflective surfaces on glass. Thin Solid Films 1999, 351, 73-78.

[18] Chen, J.J.; Sun, K.W. Enhancement of the light conversion efficiency of silicon solar cells by using nanoimprint anti-reflection layer. Sol. Energy Mater. Sol. Cells 2010, 94, 629-633.

[19] Forberich, K.; Dennler, G.; Scharber, M.C.; Hingert, K.; Fromherz, T.; Brabec, C.J. Performance improvement of organic solar cells with moth eye anti-reflection coating. Thin Solid Films 2008, 516, 7167-7170.

[20] Wu, D.; Zhao, Y.B.; Wu, S.Z.; Liu, Y.F.; Zheng, H.; Zhao, S.; Feng, J.; Chen, Q.D.; Ma, D.G.; Sun, H.B. Simultaneous efficiency enhancement and self-cleaning effect of white organic light-emitting devices by flexible antireflection films. Opt. Lett. 2011, 36, 2635-2637.

[21] Jeong, S.H.; Kim, J.K.; Kim, B.S.; Shim, S.H.; Lee, B.T. Characterization of SiO2 and TiO2 films prepared using rf magnetron sputtering and their application to anti-reflection coating. Vacuum 2004, 76, 507-515.

[22] Wwillely, R. R. (2002). Practical Design and Production of Optical Thin Films. New York, Basel: Marcel Dekker,Inc.

[23] H. A. Macleod, Thin Film Optical Filters (McGraw-Hill Company, New York, (1986).

[24] B.S. Verma; A. Basu; R. Battacharyya and V.V. Shah, " General Expression for the Reflectance of an All-Dielectric Multilayer Stack", Appl. Opt. Vol. 27, pp. 4110-4116, (1988).

[25] H A Macleod “ thin-film optical filters, third edition “, Top , university of Arizona ,1999 